\title{
Improving the active involvement of stakeholders and the public in flood risk management - tools of an involvement strategy and case study results from Austria, Germany and Italy
}

\author{
M. Fleischhauer ${ }^{1}$, S. Greiving ${ }^{1}$, F. Flex ${ }^{1}$, M. Scheibel $^{2}$, T. Stickler ${ }^{3}$, N. Sereinig ${ }^{4}$, G. Koboltschnig ${ }^{4}$, P. Malvati ${ }^{5}$, \\ V. Vitale ${ }^{5}$, P. Grifoni ${ }^{6}$, and K. Firus ${ }^{7}$ \\ ${ }^{1}$ Technische Universität Dortmund, Institut für Raumplanung, Dortmund, Germany \\ ${ }^{2}$ Wupperverband, Wuppertal, Germany \\ ${ }^{3}$ Umweltbundesamt GmbH, Vienna, Austria \\ ${ }^{4}$ Amt der Kärntner Landesregierung (AKL), Klagenfurt, Austria \\ ${ }^{5}$ Autorità di Bacino Fiume Tevere, Rome, Italy \\ ${ }^{6} \mathrm{CNR}$ - Istituto di Ricerche sulla Popolazione e le Politiche Sociali, Rome, Italy \\ ${ }^{7}$ T6 Società Cooperativa, Rome, Italy
}

Correspondence to: M. Fleischhauer (mark.fleischhauer@tu-dortmund.de)

Received: 18 November 2011 - Revised: 13 June 2012 - Accepted: 17 July 2012 - Published: 11 September 2012

\begin{abstract}
The EU Flood Risk Management Directive 2007/60/EC aims at an active involvement of interested parties in the setting up of flood risk management plans and thus calls for more governance-related decision-making. This requirement has two perspectives. On the one hand, there is (1) the question of how decision-makers can improve the quality of their governance process. On the other hand, there is (2) the question of how the public shall be appropriately informed and involved. These questions were the centre of the ERA-Net CRUE-funded project IMRA (integrative flood risk governance approach for improvement of risk awareness) that aimed at an optimisation of the flood risk management process by increasing procedural efficiency with an explicit involvement strategy. To reach this goal, the IMRA project partners developed two new approaches that were implemented in three case study areas for the first time in flood risk management:

1. risk governance assessment tool: An indicator-based benchmarking and monitoring tool was used to evaluate the performance of a flood risk management system in regard to ideal risk governance principles;
\end{abstract}

2. social milieu approach: The concept of social milieus was used to gain a picture of the people living in the case study regions to learn more about their lifestyles, attitudes and values and to use this knowledge to plan custom-made information and participation activities for the broad public.

This paper presents basic elements and the application of two innovative approaches as a part of an "involvement strategy" that aims at the active involvement of all interested parties (stakeholders) for assessing, reviewing and updating flood risk management plans, as formulated in the EU Flood Risk Management Directive 2007/60/EC.

\section{Introduction}

The 2nd Funding Initiative on "flood resilient communities - managing the consequence of flooding" (launched in 2008 by the FP6 ERA-Net CRUE project) stressed that a particular challenge for governmental institutions and water authorities is to strengthen public participation in the establishment of future approaches to flood risk management. This is in line with the requirements of Article 10 of the EU Flood Risk Management Directive 2007/60/EC (also known as the EU Floods Directive) which aims at an active involvement of interested parties in the setting up flood risk management plans. Public participation therefore is much more than just an information campaign with regard to final results: "Member States shall encourage active involvement of interested 
parties in the production, review and updating of the flood risk management plans [...]" (Article 10, § 2, EU Flood Risk Management Directive 2007/60/EC). This is necessary because stakeholders and possibly affected people have to work together for managing flood risks, and therefore there is a need to get all parties involved from the beginning.

This becomes even more important against the background of climate change. Decisions in the area of so-called "traditional" risks like flooding are normally based on probabilities, because they are past-oriented and informed by statistics, assuming that what is known about the past can be extrapolated for the future. Climate change-related effects on temperature and precipitation, however, will certainly lead to new uncertainties, because past events might not be representative anymore. For new "uncertain" risks (Milly et al., 2008), however, the perspective changes in tendency from probability to possibility, and, furthermore, technical measures are limited in their effect. Uncertain risks are characterised by possible, new, imaginable hazards, unknown coupling of processes, no or limited experience, complex causalities, multiple, heterogeneous and long-term effects. Therefore, there is no scientific or historic proof but they cannot be fully refuted either. The role of science in this context is problematic, because science cannot give a proof of risk and cannot guarantee safety. Science in this context is inconclusive (van Asselt, 2005).

With public decision-making not having any precise information at hand, restrictions (e.g. for private property rights) are probably not legally justifiable anymore. Hereby, an agreement on thresholds and response actions becomes more important. Moreover, measures, based on mandatory decisions of public administration as well as measures that are the responsibility of private stakeholders, need to be accepted widely for their implementation. Having these facts in mind, the "active involvement", propagated by the EU Flood Risk Management Directive, has to be seen as crucial for the success of the directive's main objective, the reduction of flood risks. To this respect, the following two main research questions related to communication and participation approaches were formulated for the project:

- How can stakeholder and public involvement be improved in risk communication?

- How can the quality and fairness of the flood risk management processes be guaranteed?

This article presents the development and application of new tools for communication, participation and optimisation of a flood risk governance process at the local level: a tool for targeted risk communication and a risk governance assessment tool that both potentially are vital elements of any "involvement strategy".

\section{Methodology and conceptual approach}

To have a framework based on well-grounded theory as well as a procedural guideline for the practical implementation, a scientific research concept was developed. It consisted of

- the description of the state of the art of flood risk communication and participation, and

- a concept for implementing the two innovative elements of the involvement strategy in selected case study areas.

The concept was based on desktop research, taking into account existing literature as well as results of current and finished research projects on the management of risks. To ensure a high quality of the scientific approach, it was discussed with external international experts from the field of flood risk management in a scientific colloquium. The results from this scientific colloquium were used to fine-tune the concept before starting with the implementation phase in case studies.

After the implementation of the governance concept in the case study areas, the results were discussed with scientists as well as practitioners in a second scientific colloquium that focused on the validation and evaluation of the concept.

\subsection{Procedural efficiency as a key approach}

The EU Flood Risk Management Directive 2007/60/EC requires that relevant parties are actively involved in setting up management plans in order to increase the quality, acceptance and implementation of flood risk management plans. This is in line with the concept of risk governance as introduced e.g. by the IRGC (2005).

Risk governance is a process by which risk information is collected, analysed and communicated, and management decisions are taken. It is therefore related to the institutional and procedural dimension of resilience: resilience is determined "by the degree to which the social system is capable of organizing itself to increase its capacity for learning from past disasters from better future protection and to improve risk reduction measures" (UNISDR, 2004).

The risk governance approach aims at enhancing the disaster resilience of a society (or a region) and includes "the totality of actors, rules, conventions, processes, and mechanisms concerned with how relevant risk information is collected, analysed and communicated and management decisions are taken" (IRGC, 2005).

Deficits in risk governance practices can reduce the capacity of communities for resiliency and adaptation. Therefore, two main dimensions have to be considered:

- misfits in interplay between different institutions, involved in risk assessment, communication and management (problem of interplay; Young, 2002),

- misfits between institutions and stakeholders (Löfstedt, 2005). 
Ensuring a stakeholder-focused process means consulting and involving not only stakeholders but also the public like people living in the vicinity of risky infrastructure (possibly affected people). Stakeholder is a much used term and can be used in a narrow sense of the word or with a broader understanding (Carina and Keskitalo, 2004). Sometimes "stakeholder" is used for groups with a specific longterm objective and a clear institutionalised organisational structure (= organised public e.g. chambers). Often organisations of civil society like human rights and environmental organisations (NGOs) are included in this understanding. In scientific projects, the term stakeholders is often used for representatives of the institutionalised public and of (noninstitutionalised) organised interest groups. In contrast, the Intergovernmental Panel on Climate Change (IPCC) or the World Bank have a broader understanding of the term stakeholder: it is everybody that is affected or interested by a project/activity. Strong stakeholder-oriented elements have been integrated in disaster management strategies like the United Nations International Strategy for Disaster Reduction (UNISDR, 2005).

Participation and information support in most cases a higher quality of decisions, help to reach an agreement on open questions or help to effectively implement decisions that are made by public as well as private actors. In those cases where an agreement is not achievable, the participants are included in a process of social learning and come at least to a better understanding of the different interests and values. Consequently, the involvement of all social groups into a stakeholder dialogue is regarded as crucial for any risk governance concept. However, including lay persons or stakeholders in a (natural science-based) dialogue about risk management is not always an easy task.

A key element to deal with the mentioned challenges is to involve the stakeholders - as suggested in the EU Flood Risk Management Directive - from the beginning. Some of the problems such as distrust in authorities, lack of access to decision-making, difficulties in understanding, nontransparency, missing stakeholder involvement and problems with the acceptance or practicability of measures can be reduced with governance-related approaches.

However, many approaches and methods cannot be transferred easily to other social systems or cultural backgrounds due to differences in risk perception, administrative traditions, access to resources, etc. This is a challenge EU legislation always has to deal with and which increases with every new member state. Thus, EU legislation does not force member states to implement certain instruments or methods - being aware of their failure in cases they are not approved and accepted by the relevant stakeholders and the public. The European Commission sets the frame for procedural requirements (e.g. EU Strategic Environmental Assessment Directive 2001/42/EC), and member states have to apply their tools and techniques as well as legislation in order to be able to act along the prescribed common objectives, definitions and cer- tain procedural steps. In the end, procedural efficiency can enhance improved material standards for risk management and governance and fosters therefore resilience.

\subsection{Role of informal participation}

A key to a successful procedural approach is to open a risk management process to informal participation elements. Formal participation (e.g. the legal status of land owners) is legally defined in flood risk management processes. However, this formal participation can be extended by informal, voluntary participation in order to improve the efficiency and acceptance of the flood risk management process and the following structural and non-structural measures. Informal participation processes should not be seen as a substitute or competing with formal processes, but can support these. This informal participation and the related communication tools can be designed in various ways, and it was an aim of the project to identify the options for designing an informal communication and participation process.

Additional public participation activities are (after Bundeskanzleramt and BLFUW, 2009) particularly recommendable where

- many people are affected by or interested in the topic;

- the topic might be controversial;

- the implementation of the policies, plans, programs, and legal instruments requires the cooperation with those affected and interested;

- a broader comprehension, acceptance, and a result of high quality are aimed at or for settings characterised by uncertainty and ambiguity.

The intensity of public participation can vary within a process. The basis for all participation processes is free access to information. However, simple information activities like a website or a dissemination flyer do not count as "real" participation activities. They consist only of one-way communication, and, even if it is the necessary basis, the main characteristic of participation activities is missing: the element of dialogue (Fig. 1).

How binding the solutions or results of a voluntary participatory process are depends on what method has been agreed on in order to treat the results. Results can potentially become legally binding, e.g. via a mediation contract, a city council decision, etc. (Arbter et al., 2005), but at least it will help to support the decisions by most of the affected people. 
Participation in decision making process

Round table working group mediation, etc.

Consultation

Discussion event, proposals, statements, questionnaires, etc.

\section{Information}

Flyers, website, information day, presentation of maps of selected sites, etc.

Fig. 1. Intensity degrees of participation processes (source: after Arbter et al, 2005, p. 9).

\section{Application of the innovative approaches in three case studies}

This section describes the two innovative approaches of the involvement strategy and its implementation in three case study areas:

- a mid-European hilly land river basin district, densely built-up, mainly prone to winter floods and flash floods: the river Wupper (Germany);

- an Alpine river basin, prone to flash floods and debris flows: the river Möll (Austria);

- a Mediterranean river basin, prone to torrential floods: the river Chiascio (Italy).

The three case study areas further represent different environmental and socio-economic settings as well as two different legal and administrative backgrounds (Table 1). The choice of different legal and administrative backgrounds in the case studies is helpful as the existing legal framework serves as normative basis for any risk assessment and risk management, to be taken by public as well as private bodies. This frame differs considerably among European countries and can be grouped into different administrative families (Newman and Thornley, 1996, p. 29). Apart from legal factors, individual risk perception is also shaped by how the community or a certain socio-cultural milieu generally deals with a special type of risk or risky situations. What applies to individuals can also be observed between different societies that each share a common legislative and cultural basis. An important and interesting aspect of risk perception is thus the variation in different cultural (regional, national) contexts, a perspective studied within the cultural risk paradigm. Risk perception enters the risk management equation through differing estimations on, for example, how probable an event may be, and how much money is to be spent on preparedness.

The given differentiation in legal and administrative families influences particularly the way in which decisions are taken and prevention actions are planned, though the EU
Floods Directive sets a common ground. In some of the EU member states (particularly in the Germanic family), a new development is legally allowed when it is conforming to the land use as laid down in legally binding plans. This so-called regulatory function of planning is known under the term "conforming planning" in the international discourse on planning theory (Rivolin, 2008; Larsson, 2006). In other EU member states (i.e. the Napoleonic family), the so-called development function dominates, which is discussed under the term "performing planning". This planning type is characterised by legally non-binding programmatic and/or strategic statements. Potential projects are then evaluated against the question of whether they support the implementation of the programme or strategy. Furthermore, there are - if at all only partially binding effects for the subordinated local level.

However, the legal framework determines how strategies and measures for risk management are designed and by which institutions they are implemented. As an example, the setting of legally binding and spatially specific objectives (e.g. to keep an area free of further settlement development) presumes that there are laws enabling the enactment and enforcement of such spatial objectives. Thus, the differences in the planning systems shall be taken into consideration for deriving management options.

\subsection{Optimising the flood risk management process: risk governance assessment tool}

\subsubsection{Description of the tool}

The problem of interplay among institutions (lack of vertical and horizontal cooperation of stakeholders, Young, 2002) is often a major reason for the ineffectiveness of management strategies and measures as well as the lack of public participation. Misfits in both might enhance the institutional vulnerability which can be seen as one of the main aspects in dealing with risks, because the whole disaster cycle from mitigation, preparedness, response to recovery is embedded in an institutional system including the public. Thus, there is the need to design a risk governance approach that relates to basic and commonly accepted values of good risk governance, e.g. as described by the International Risk Governance Council (IRGC, 2005, 2009).

The risk governance assessment tool that was adapted for flood risk management activities is based on these principles and shall support the responsible authority for implementing a flood risk management strategy to carry out a self-assessment of its own flood risk governance performance. During the flood risk management process, this assessment can be validated by an external assessment of the co-operating stakeholders.

Table 2 gives a comprising overview of keywords, objectives and specific indicators that can be seen as elements of an ideal risk governance process (MIDIR project, 2008). The idea behind it is to evaluate a governance process along these 
Table 1. Case study areas (source: AKL, AB Tevere, Wupperverband).

\begin{tabular}{|c|c|c|c|}
\hline Characteristics & $\begin{array}{l}\text { River Möll, Austria (Federal } \\
\text { State of Carinthia) }\end{array}$ & $\begin{array}{l}\text { River Wupper, Germany (Federal } \\
\text { State of North Rhine-Westphalia) }\end{array}$ & $\begin{array}{l}\text { River Chiascio, Italy (Region of } \\
\text { Umbria) }\end{array}$ \\
\hline Major type of flood & mainly fluvial & mainly fluvial, partly pluvial & pluvial, fluvial \\
\hline $\begin{array}{l}\text { Size of catchment } \\
\text { area }\end{array}$ & $1105 \mathrm{~km}^{2}$ & $813 \mathrm{~km}^{2}$ & $727 \mathrm{~km}^{2}$ \\
\hline Past flood events & $\begin{array}{l}\text { September 1965; } \\
\text { November } 1966\end{array}$ & $\begin{array}{l}\text { February 1909, December } 1925, \\
\text { February 1946, 1960s, December } \\
\text { 2007, January } 2011\end{array}$ & $\begin{array}{l}1937 \text { (last large event), Novem- } \\
\text { ber } 2005 \text {, December 2008, Jan- } \\
\text { uary } 2011\end{array}$ \\
\hline $\begin{array}{l}\text { Environmental } \\
\text { settings }\end{array}$ & $\begin{array}{l}\text { River Möll rises as a torrent } \\
\text { from a glacier tongue at about } \\
2400 \mathrm{~m} \text { a.s.l. and flows into river } \\
\text { Drau after } 70 \mathrm{~km} \text { at } 550 \mathrm{~m} \text { a.s.l. } \\
\text { Its tributaries are mountain tor- } \\
\text { rents with steep inclines and an } \\
\text { inherent risk potential for land- } \\
\text { slides and a strong impact on the } \\
\text { bed load of the river Möll. }\end{array}$ & $\begin{array}{l}\text { The Wupper is a tributary of the } \\
\text { river Rhine and owns a medium } \\
\text { discharge of about } 15.4 \mathrm{~m}^{3} \mathrm{~s}^{-1} \\
\text { linked with an annual precipita- } \\
\text { tion of up to } 1425 \mathrm{~mm} \mathrm{~m}^{-2} \text {. The } \\
\text { riverbed of the Wupper lies be- } \\
\text { tween } 441 \mathrm{~m} \text { a.s.l. (spring) and } \\
34 \mathrm{~m} \text { a.s.l. (mouth). }\end{array}$ & $\begin{array}{l}\text { River basin is delimited by the } \\
\text { Apennine Mountains (height of } \\
\text { over } 1000 \mathrm{~m} \text { a.s.l.), characterised } \\
\text { by calcareous and permeable } \\
\text { rocks. Groundwater circulation } \\
\text { feeds some perennial springs that } \\
\text { originate short watercourses with } \\
\text { significant flows also in the dry } \\
\text { season. The Chiascio is a tribu- } \\
\text { tary of the river Tiber. }\end{array}$ \\
\hline $\begin{array}{l}\text { Socio-economic } \\
\text { settings }\end{array}$ & $\begin{array}{l}18600 \text { residents (catchment } \\
\text { area); important economic fields } \\
\text { are agriculture (grassland and } \\
\text { forestry), hydropower and } \\
\text { tourism. }\end{array}$ & $\begin{array}{l}\text { Case study town of Leichlingen; } \\
\text { population of about } 25000 \text {; part } \\
\text { of the Rhein agglomeration area, } \\
\text { regional centre of fruit growing; } \\
\text { public seems not to be really } \\
\text { aware of the potential flood risk } \\
\text { due to the fact that the last large } \\
\text { flood occurred } 1925 \text {. }\end{array}$ & $\begin{array}{l}\text { Intense agricultural activities, } \\
\text { several industrial production } \\
\text { and urban agglomerates; about } \\
67000 \text { inhabitants. }\end{array}$ \\
\hline $\begin{array}{l}\text { Legal/administrative } \\
\text { planning family }\end{array}$ & Germanic & Germanic & Napoleonic \\
\hline
\end{tabular}

indicators and illustrate these by a rather self-explanatory five-colour code. An appropriate classification allows the assessment of the performance of a process. In accordance with the scorecard methodology (Website Balanced Scorecard, 2011; MIDIR project, 2008), five levels were suggested, running from red (= initial phase/not started: no formal process started yet) over yellow (= definition phase/developing: processes described in standards, tools and methods) to blue (= optimising phase/improving: data are used to continuously improve processes).

To get a proper overview of the actual status of the risk governance process, the responsible authority (selfassessment) and the involved stakeholders (external assessment) are, for example, asked how they judge the degree of operationalisation of the guiding principles (keyword "principles"). Or both are asked about the access to information, which means the availability and understandability of the relevant information for stakeholders. This tool provides an opportunity for the authority to get straightforward feedback about how they are seen by the stakeholders related to the main fields of action in risk governance processes. A dis- crepancy between internal and the external ratings indicates that there is a need for vertical or horizontal cooperation, respectively an exchange of information.

\subsubsection{Application in case study areas and assessment of tool}

In the three case study areas in Austria, Germany and Italy, the risk governance assessment tool was applied firstly by the responsible authorities for the flood risk management process as a self-assessment. Secondly, relevant stakeholders ("interested parties") in the case study areas were asked to assess the work of the responsible authority externally. During stakeholder workshops in the case study areas, the risk governance assessment tool was presented to the participants. The workshop participants represented - depending on the case study area - stakeholders from communities, emergency management, flood risk management, land use planning, economic development, environmental planning, etc. from the local as well as regional level (and in the Austrian case study also once from the national level). 
Table 2. Overview of key performance indicators (source: MIDIR project; 2008, p. 8).

\begin{tabular}{|c|c|c|c|}
\hline Keyword & Key question & Objective & Key performance indicator \\
\hline Principles & What are the guiding principles? & $\begin{array}{l}\text { Definition of guiding principles } \\
\text { and a consistent "target system". }\end{array}$ & $\begin{array}{l}\text { Degree of operationalisation of the } \\
\text { guiding principles. }\end{array}$ \\
\hline Trust & $\begin{array}{l}\text { How far is attention paid to rele- } \\
\text { vance of an atmosphere of mutual } \\
\text { respect and trust? }\end{array}$ & $\begin{array}{l}\text { An atmosphere of mutual respect } \\
\text { and trust exists between all rele- } \\
\text { vant stakeholders and decision } \\
\text { makers. }\end{array}$ & $\begin{array}{l}\text { Reflection of trust concerning peo- } \\
\text { ple/institutions. }\end{array}$ \\
\hline Objectives & $\begin{array}{l}\text { What are the concrete protection } \\
\text { goals for subjects of the protect- } \\
\text { ion? }\end{array}$ & $\begin{array}{l}\text { Definition of a comprehensive and } \\
\text { obligatory understanding of the } \\
\text { damage-protection relation. }\end{array}$ & $\begin{array}{l}\text { Degree of obligation concerning } \\
\text { the protection goals for the sub- } \\
\text { jects of the protection. }\end{array}$ \\
\hline $\begin{array}{l}\text { Accountability } \\
\text { principle }\end{array}$ & $\begin{array}{l}\text { How far is accountability defined } \\
\text { at each level (process, each risk)? }\end{array}$ & $\begin{array}{l}\text { Each actor knows his/her responsi- } \\
\text { bilities and acts accordingly. }\end{array}$ & Definition of the responsibility. \\
\hline Justification & $\begin{array}{l}\text { How far is the activity concerning } \\
\text { the management of existing risks } \\
\text { justified? }\end{array}$ & $\begin{array}{l}\text { Justification of action in the area of } \\
\text { risk management. }\end{array}$ & $\begin{array}{l}\text { Definition and agreement on a jus- } \\
\text { tification concerning the exposure } \\
\text { to risk. }\end{array}$ \\
\hline Representation & $\begin{array}{l}\text { How far are all relevant social } \\
\text { groups (and their representatives, } \\
\text { stakeholder respectively) and their } \\
\text { expectations known? }\end{array}$ & $\begin{array}{l}\text { Identification of all relevant social } \\
\text { groups and their expectations. }\end{array}$ & $\begin{array}{l}\text { Degree of high profile of all social } \\
\text { groups and their expectations. }\end{array}$ \\
\hline $\begin{array}{l}\text { Access to } \\
\text { information }\end{array}$ & $\begin{array}{l}\text { How far is information for all } \\
\text { stakeholders accessible? }\end{array}$ & $\begin{array}{l}\text { Access for all stakeholders to the } \\
\text { relevant information. }\end{array}$ & $\begin{array}{l}\text { Degree of the availability and } \\
\text { understandability of the relevant } \\
\text { information for stakeholders. }\end{array}$ \\
\hline $\begin{array}{l}\text { Tolerance process } \\
\text { and outcome }\end{array}$ & $\begin{array}{l}\text { How far do the stakeholders toler- } \\
\text { ate/accept the risk governance pro- } \\
\text { cess and its outcomes? }\end{array}$ & $\begin{array}{l}\text { All involved stakeholders tolerate/ } \\
\text { accept the risk governance process } \\
\text { and its outcomes. }\end{array}$ & $\begin{array}{l}\text { Degree of the tolerance/acceptance } \\
\text { on the part of involved stakeholder. }\end{array}$ \\
\hline Dialogue & $\begin{array}{l}\text { To what extent is a constructive di- } \\
\text { alogue with the relevant stakehold- } \\
\text { ers available or conducted? }\end{array}$ & $\begin{array}{l}\text { Establishment of custom dis- } \\
\text { course-processes concerning } \\
\text { risk topics. }\end{array}$ & $\begin{array}{l}\text { Quality of discourse-processes } \\
\text { with relevant stakeholders } \\
\text { (i.e. public or private representa- } \\
\text { tives). }\end{array}$ \\
\hline Financial resources & $\begin{array}{l}\text { To what extent do the available fi- } \\
\text { nancial resources meet the require- } \\
\text { ments of the defined risk gover- } \\
\text { nance process? }\end{array}$ & $\begin{array}{l}\text { Allocation of sufficient financial } \\
\text { resources for a successful risk } \\
\text { governance process. }\end{array}$ & $\begin{array}{l}\text { Degree of realisation of a financial } \\
\text { concept. }\end{array}$ \\
\hline Staff resources & $\begin{array}{l}\text { To what extent do the staff } \\
\text { resources (technical qualification } \\
\text { and number of people) meet the } \\
\text { requirements of the defined risk } \\
\text { governance process? }\end{array}$ & $\begin{array}{l}\text { Allocation of adequate staff } \\
\text { resources. }\end{array}$ & $\begin{array}{l}\text { Realisation of a staff assignment } \\
\text { concept. }\end{array}$ \\
\hline Role & $\begin{array}{l}\text { How far has the role of experts } \\
\text { been defined? }\end{array}$ & $\begin{array}{l}\text { If experts are involved, their role } \\
\text { within the decision-making } \\
\text { process has to be defined. }\end{array}$ & $\begin{array}{l}\text { Degree of definition and agreement } \\
\text { concerning the role of experts. }\end{array}$ \\
\hline Co-ordination & $\begin{array}{l}\text { How large is the degree } \\
\text { of fragmentation of responsi- } \\
\text { bilities between the different } \\
\text { actors/stakeholders? }\end{array}$ & $\begin{array}{l}\text { Co-ordination of actions in order to } \\
\text { reduce misfits due to the fragmen- } \\
\text { tation of responsibilities. }\end{array}$ & $\begin{array}{l}\text { Realisation of a concept to } \\
\text { co-ordinate decision-making } \\
\text { procedures. }\end{array}$ \\
\hline Co-operation & $\begin{array}{l}\text { To what extent do the } \\
\text { actors/stakeholders follow their } \\
\text { own rationale in preparing and } \\
\text { making decisions? }\end{array}$ & $\begin{array}{l}\text { Agreement on the process of how } \\
\text { responsibilities are allocated to } \\
\text { a decision-preparing or decision- } \\
\text { making structure. }\end{array}$ & $\begin{array}{l}\text { Degree of definition and agreement } \\
\text { concerning the responsibilities of } \\
\text { stakeholders. }\end{array}$ \\
\hline
\end{tabular}


The risk governance assessment was carried out twice in all case study areas: in the beginning in 2010 (for a status quo analysis) and at the end of the project in 2011 (to show the improvement due to the project activities).

In Austria, the indicators for the assessment of the risk governance process were not easily understood by the stakeholders. Thus, some additional effort for an interpretation of indicators was needed. Sometimes the indicators even had to be re-interpreted during the two self-assessment rounds. The self-assessment was done first by the Regional Water Authority (AKL) for the valley of the river Möll and then by the Federal Ministry of Agriculture, Forestry, Environment and Water Management for the entire Austrian situation. The results of the two assessments showed similarities in most of the positions. The Austrian project partners were not able to completely apply all fields of the assessment as Austria already has a tradition of administration and law of how to deal with flood risk. In many areas, the indicators are formally and clearly defined and without much scope. Many principles, goals, responsibilities, etc. cannot be influenced by AKL, because they are already defined by law or other regulations. But the indicators were seen as a tool to structuralise and prioritise the discussion on co-operation fitness in areas that are informal and/or without administrative tradition. The assessment results showed room for improvement. However, an improvement of the situation often depends on an allocation of resources (e.g. for participation activities), which is not the responsibility of the partners.

In Germany, the Regional Water Authority (Wupperverband) adjusted the indicator set according to its own use. The German project partners concluded that the assessment tool was useful for internal benchmarking/assessment but that it first was hardly used by external stakeholders in order to assess the work of the Wupperverband. The reason was that it needed some preparation to understand the logic of the approach. Thus, the assessment tool was presented more intensively during the second stakeholder workshop with the result of a much better participation. As a result, there were some similarities between internal and external assessment but in some points the Wupperverband estimated its position much better than the external experts did. Figure 2 displays the results of the second self-assessment as well as the external assessment. For some indicators, there are similarities between the internal and external perspective; for others, there are rather large differences. As one example, a high consensus exists for the indicator "trust", apart from two stakeholders, who deny the existence of an atmosphere of mutual respect and trust between all relevant stakeholders and decision makers. A rather large difference exists for the indicator "justification" where the Wupperverband has the opinion that the management of existing risks is not justified adequately in contrast to the majority of the external stakeholders. The quite large number of "no answers", however, showed that not every stakeholder was able to assess the performance for all indicators due to a lack of insight into the process (dif-

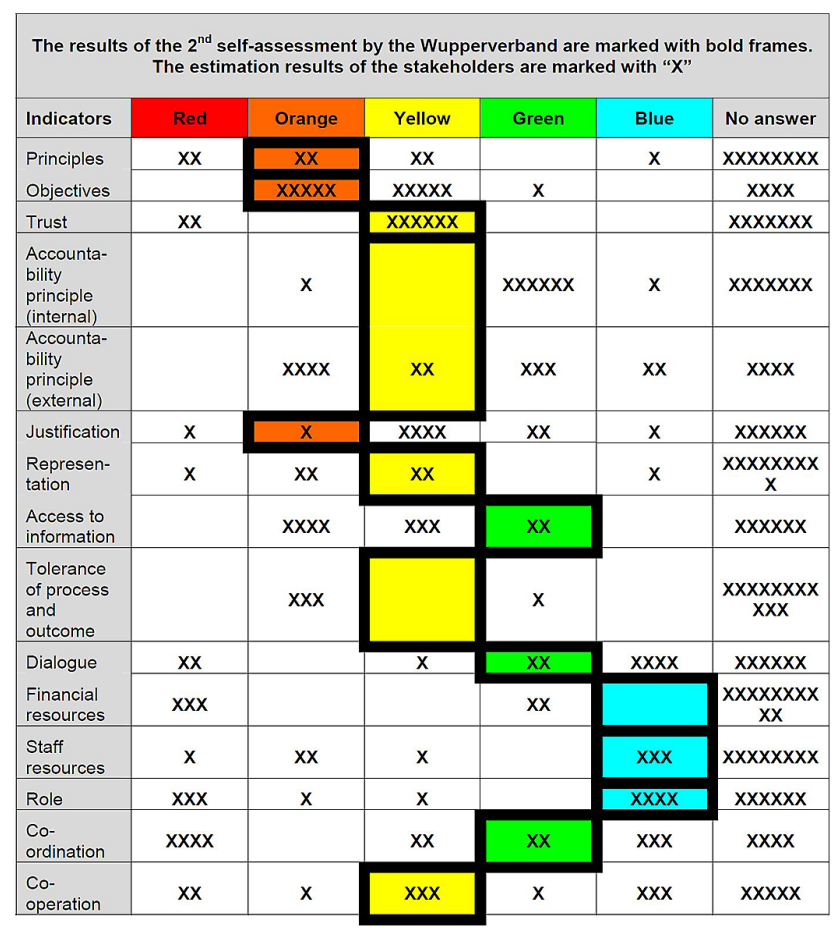

Fig. 2. Self-assessment of the local water authority (Wupperverband) in the German case study and stakeholders at the end of the project in 2011 (source: Firus et al., 2011).

ferent backgrounds and knowledge) or due to a low experience with such assessment tools. Many of them felt unable to gauge to what extent, for example, the available financial resources of the authority in charge met the requirements of the defined risk governance process. Thus, it would have been beneficial to customise the assessment tool even more to the level of understanding and the needs of the addressed stakeholders. Overall, it can be concluded that the indicator set is most important as an internal assessment tool in order to structuralise and prioritise issues on flood risk management and to show where either improvements have to be made or where the information policy of the authority has to be improved.

In the Italian case study, the indicator system was also adjusted to the institutional and legal background. In Italy some developments with regard to some indicators were made between the first and second assessment (e.g. the indicator values for dialogue and co-operation improved). In addition, the use of the indicators became more familiar in the second assessment round. The Italian partners summarised that the indicator-based assessment seemed to be a good way to analyse the performance of the organisation, as it provided a clear structure. It is a new way of monitoring in the administration. Solely discussing the indicators and the values already highlighted some issues that were previously not taken into consideration. However, some difficulties occurred; as the Tiber River Basin Authority is a public body under national law, 
the main indicators such as principle, trust, coordination, cooperation, responsibility etc. are concepts already predefined by national law.

\subsection{Target group-oriented communication: social milieu approach}

\subsubsection{Description of the approach}

Scientists, and especially those coming from engineering disciplines, tend to stick to the belief that it is possible to reach everybody with one communication mean, e.g. to reach all people potentially affected by flood risk with one flyer (Stickler et al., 2011). From communication theory and market research we know that information material and activities have to be custom-made in order to reach specified target groups. This is due to the fact that risk perception is influenced by individual and cognitive determinants.

Generally speaking, each individual is embedded in the interpretative culture of a society or social group, which can be understood as a filter for many individual processes. It is essential to know these individual processes in addition to the social ones, as the former often contribute to establishing or modifying the social and societal interpretative culture.

1. The degree of voluntariness of a human being to exposure plays a key role in the risk perception of this person. Risks to which people are exposed against their will are usually felt to be larger than those to which they have taken voluntarily. Acceptance is generally lower for non-voluntary risks (e.g. pollution by industrial emissions in comparison with smoking).

2. The experience had with a certain risk is a further determinant of risk perception. Adverse previous experience with a hazard contributes to an individual feeling that the risk is very high and taking active preventive measures. Even if people have no personal experience with acute hazards, as is e.g. the case for the possible consequences of climate change, risks can be viewed as very high. This is particularly the case if such hazards are hard to perceive, are not individually controllable and the potential damage is very high. In consequence, such risks are called "dread risks".

3. People who do not feel affected by a potential damage generally perceive the risk as lower than others who expect to be seriously harmed in the event that the risk occurs (e.g. residents of an earthquake-prone area).

4. Risks that appear uncontrollable to the individual are felt to be very threatening. These include events that cannot be changed by the actions of the individual. People living in a high-risk situation that escapes their control usually have few alternatives for coping.

5. Risks can be evaluated differently depending upon the level of knowledge. It is often assumed that people feel threatened by situations where they have no precise knowledge or they have no information to assess the potential damage. However, the relationship between knowledge and assessments of hazardousness is more complex. Knowledge alone is not decisive for the assessment of threat. It is always mingled with other factors, such as values, attitudes or opportunities for protection.

6. For the perception and acceptance of large-scale technologies in particular, attitudes have proven to be an important factor. Evaluations of nuclear energy, for instance, are regularly embedded in general values and ideologies.

7. Well-known and familiar risks are generally perceived as less threatening than new, still unknown ones (Slovic, 1987).

Cognitive factors play an important role concerning the individual determinants of risk perception. When individuals ("non-experts") are asked to estimate the probability of occurrence of certain events, it has been found that such probability estimates are frequently subject to certain systematic errors. These errors are caused by cognitive "rules of thumb" (heuristics) which people normally use in everyday life to estimate certain events. Whenever these heuristics are used to estimate risks, however, they generally are unsuited (Slovic et al., 1985).

Experts tend to assess risks according to statistics and other "objective" technical methods, whereas the estimation by non-experts (laypeople) is influenced by a variety of further factors such as values, attitudes, social influences or cultural identity. The following heuristics are typical for nonexperts or laypeople (WBGU, 2000, p. 168):

1. Events that are easy to remember are rated as more probable than events that are less mentally available (e.g. the risk of an airplane crash versus that of a cardiovascular disease). Events mentally available are those that are frequently or have recently been reported in the media or that make a particular impression. Less spectacular risks, in contrast, are underestimated although the risk of dying from a cardiovascular disease is many times higher than that of dying in an airplane crash.

2. Laypeople are prone to the gambler's fallacy. Developed from observations of people rolling dice, this means in risk research that people who have just suffered damage believe that such events are not to be expected in the near future. This is based on the often misleading assessment that an event that is improbable in any case will not occur several times in succession. This is fallacious because the probability of occurrence permits no statement as to the time or sequence of events (Burton et al., 1978). 
3. Events are assessed as more risky when framed in terms of (potential) losses and not of "gains" (e.g. survivors). Thus, one and the same risk is viewed as being higher if expressed in terms of an expected death rate of $60 \%$ and viewed as lower if expressed in terms of a survival rate of $40 \%$ (Kahneman et al., 1982).

A further aspect is the phenomenon of cognitive dissonance first described by Festinger (1957; also Festinger and Carlsmith, 1959). Cognitive dissonance describes an uncomfortable feeling caused by holding two contradictory ideas simultaneously. In the context of flood hazards, it means that information that is contradictory to the individual's value system or pattern of thoughts is not perceived at all or at least played down. In the case that one's own property or home is threatened by river floods and at the same time the owner rejects or is not able to leave, the flood hazard is denied, warnings are set at nought and experts are distrusted (Bader and Kunz, 1998). Denying the existence of flood hazard on the other hand means to avoid cognitive dissonance (Wagner and Suda, 2004).

This is a major hindrance and challenge for any risk management process as it means that a well-designed communication strategy and deliberately prepared information tools may lead to nothing due to the denial of hazards and risks by individuals. To plan a risk communication strategy, it is thus necessary

- to identify the status of the knowledge and risk perception of the local population;

- to identify values and attitudes (that can affect risk perception) of the target groups.

Values, attitudes, and other socio-cultural features can be assigned to social groups, to "milieus". Research about social milieus is traditionally performed by market research and psychology. It was not planned or possible within the ERANet CRUE-funded project IMRA to perform a detailed sociocultural analysis of target groups in the regions of the subprojects. But an overview on the national level (which kind of target groups exist, what their attitude and values are and what kind of information material could reach them) gave valuable input to a risk communication strategy.

In order to have a basis for this discussion, it was decided to use the Sinus Milieus ${ }^{\circledR}$ (SINUS-Institut, 2011) developed by the market research company SINUS-Institut, Heidelberg (for Germany and Italy) and INTEGRAL, Vienna (for Austria). These Sinus Milieus ${ }^{\circledR}$ give an overview of social groups on the national level for all case studies. The social milieus for each country are characterised by a specific combination of the social status and the basic values. INTEGRAL (2011) points out that the Sinus Milieus ${ }^{\circledR}$ combine demographic characteristics such as education, profession and income with the real living environments of the people, which means with fundamental value orientations and attitudes to- wards working and leisure time, family and relationship, consumption and politics.

Understanding how values filter information and colour perceptions is of critical importance to design and implement public information campaigns (Roser-Renouf and Nisbet, 2008). It should not be neglected that there are also sceptical voices (Sjöberg, 2000) that object that the social context per se by no means is the sole determinant of risk perception. However, the social milieu approach can be regarded as valuable for building up communication strategies and therefore it was used as a working hypothesis.

According to the social milieu approach, different social groups need differently designed information material and various communication channels. One of the first steps in designing a risk communication strategy is the analysis of the public living in a hazard-prone area. According to Kleinhückelkotten (2007), the communication strategy shall be developed closely related to the existing social milieus, e.g.:

- High achiever milieu: high achievers are successoriented, have an intensive private and professional lifestyle, are flexible and interested in multimedia. A communication campaign with high achievers as addressees should develop professional and creative folders and posters, use internet/social networks and should be designed authentically and unconventionally. Cooperating partners for such a media campaign could be schools, universities (e.g. department for media design), or newly founded companies.

- Traditional/new middle class milieu: traditionalists belong to the petit bourgeoisie or the working class; the new middle class includes the status-oriented modern mainstream that looks for social and professional establishment, security and harmony. A communication campaign should make use of rather simple, informative and clear designed information sheets in churches, sport clubs, banks and post offices, at village fairs, use bulk mailing, local newspapers, official gazettes and others. Cooperating partners could be kindergartens, schools, leisure clubs, local politicians, public libraries.

These examples of a target group-oriented design of information material were extended, where needed, to other social milieus due to the demands of the case study regions.

\subsubsection{Application in case study areas and assessment}

The barriers for the analysis of the social milieus were the same in all three case studies: detailed socio-demographic data at such small scale were not available. Thus, there was the need to additionally carry out qualitative interviews with key persons to gather information about the social status and basic values in the case study areas.

In the Austrian case study area, data and information used for the analysis of social milieus were statistical data from 
Statistik Austria (Statistik Austria, 2011) about income, education and economic sectors, age and gender and additional data researched on the internet. This information was discussed with the mayor and local stakeholders who have further knowledge about the professions and education of the local population. The results of the analysis of social milieus showed that most parts of the population belong to the rural traditionalist, the working class and the middle class milieus. In the communication and participation approach, all methods and also the selection of multipliers were adjusted to the social milieus: stakeholder workshop, exhibition and workshops with stakeholders and lay people. According to the identified milieu, low-threshold approaches with a strong focus on historic local events and oral history involving the local population were implemented.

In Germany, statistical data from Information und Technik Nordrhein-Westfalen (IT.NRW, 2011) and the city of Leichlingen (Stadt Leichlingen, 2011) were used and key questions on social milieus were asked in interviews with local stakeholders. In the German case study, most parts of the population belonged to the social milieus of rural traditionalists and the middle class. Here, the identification of social milieus can be useful. They are shown in Fig. 3 for the German example. In the Wupper case study, the approach as such helped to look carefully whom to address with the elements of the communication strategy. However, this was not directly linked to certain social groups. Most of the information needed for the communication strategy was based on the interview results.

In the Italian case study, regional data about Umbria came from the Istituto nazionale di statistica (ISTAT, 2008, 2009) as well as from an internet research (Regione Umbria, 2011). The large part of the population of the Italian case study region was classified as ambitious middle class, usually sensible considering the perspectives of new generations. The identification of the social milieus helped to identify appropriate communication activities. The communication with students and teachers during meetings in different schools (with videos, games, competitions) in order to involve their families was chosen according to the social milieu of the region.

\section{Implications for the selection of communication and participation methods in a flood risk management involvement strategy}

The results from the practical application are discussed in the following sections along the main research questions related to communication and participation approaches.

\subsection{Improving public involvement and risk communication}

Decision makers and other stakeholders shall avoid the myth that an increase in information will automatically lead to increased risk awareness. Recipients only notice information if it touches subjects that are within their knowledge (Wagner, 2005; Hagemeier-Klose and Wagner, 2009). Because of the non-significant position of natural hazards in everyday life (Geipel et al., 1997), it is expected that other attitudes affect people's perception on river flooding in this case. According to Weichselgartner (2001), one can say, people are looking through specific "eyeglasses" on a topic.

In the beginning of a flood risk management process, it is essential to carry out a thorough stakeholder analysis and an analysis of the affected population. When identified, for example with the approach of the social milieus, the right people have to be addressed with the right information via the right media (or maybe even more than in one way) and an appropriate language. In all cases it is important to choose a custom-made strategy to address the different groups with the appropriate communication methods, as shown by the analysis of the Sinus Milieus ${ }^{\circledR}$. An important point for the success of any communication strategy is that people have to feel concerned. They must understand that flood risk is something that really is relevant for them and not just an administrative exercise.

One should also consider addressing multipliers as e.g. teachers or (locally) prominent persons. The ERA-Net CRUE-funded project DIANE-CM highlighted the function of so-called "local heroes" (Evers et al., 2011). Each social milieu has a different kind of multipliers. In the ERANet CRUE-funded project IMRA's activities, pupils worked also as multipliers when they reported about their class at home. The experiences in the case study in Leichlingen and in the school-related activities in the Italian case study as well showed that pupils are easy to motivate to work on the context of river flooding and have a variety of knowledge (Firus et al., 2011).

The involvement of the media can be an important additional tool to back communication and participation activities and to inform about them with the broad public as well as the multipliers. However, when, how and with what content contact with the media will happen should be co-ordinated with the involved stakeholders, especially with politicians and stakeholders from administration.

In a risk communication process, risk governance principles should be taken into account. It is required to take care of an open and transparent process (e.g. Figueiredo et al., 2009). Therefore, it always has to be ensured that information is provided and made accessible for everyone. However, one shall be aware of the social implications of flood risk management projects. Too early communication via the media about planned flood risk management activities (e.g. before agreeing with land owners on prices for land needed, 


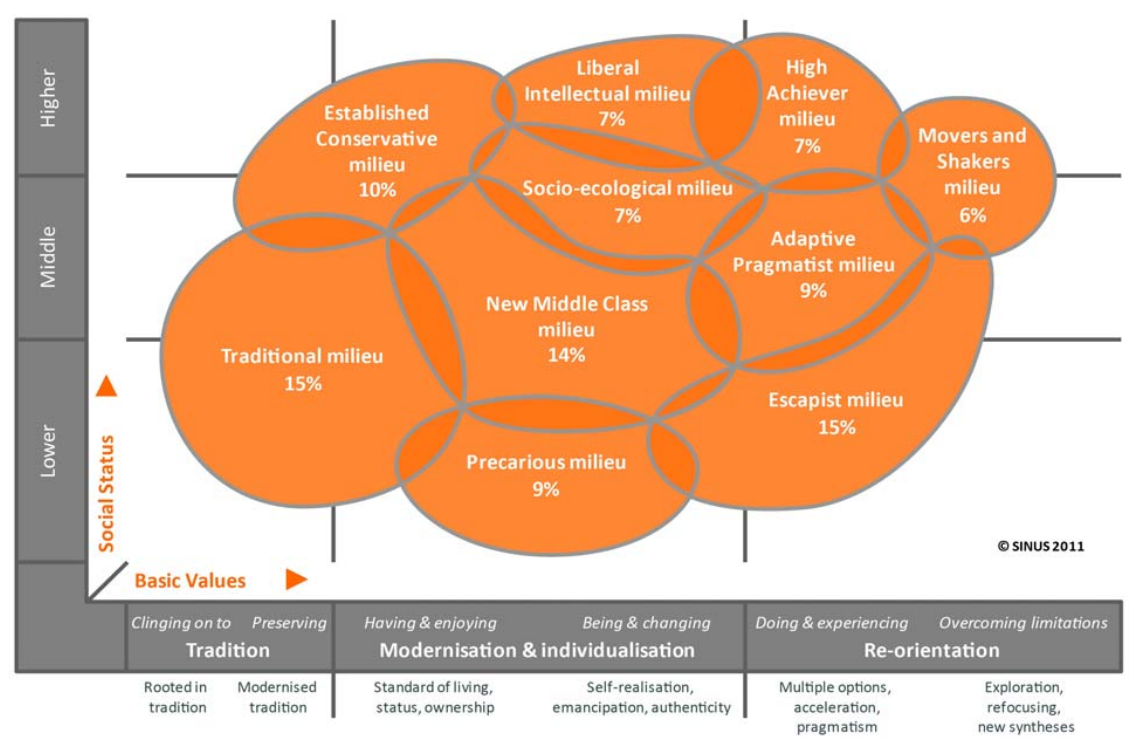

Fig. 3. Sinus Milieus ${ }^{\circledR}$ in Germany 2011 (source: SINUS-Institut, Heidelberg).

e.g. for retention area) can have adverse effects to the success of a project. Thus, the message has to be spread deliberatly.

Further, it could be reasonable to identify those stakeholders who - ideally - own a press office, as building up media contacts is a long-lasting process. Media/press will be more open for information transferred by persons that they have been working together with for quite a long time and the people know from where the information comes (seriousness of the information given and trust). That aside, one should consider the education of local media or individual journalists on the context of river flooding, especially the used modelling methods and the correct meaning of the often used terms (e.g. CARPE DIEM project, 2004).

Finally, the success of a communication strategy is also a question of the right timing. It should be taken into consideration that people have different perceptions before and after a disastrous event. Hence, measures have to be customised respectively - the window of opportunity (Kingdon, 1995) during and right after a disastrous event is the right moment to implement already prepared activities and strategies.

\subsection{Promoting long-lasting risk awareness and institutionalised participation}

It was impossible to ensure long-lasting risk awareness only by the activities within the project lifetime of two years. But tools and methods for maintaining a high level of risk awareness were initiated. However, starting points for the institutionalisation of activities on risk awareness can be found at different levels. The school programmes applied in the IMRA project should be repeated regularly. Better would be an embedding in the curriculum. No less important for a long-lasting risk awareness are activities for the broad public. People shall be reminded of past events (e.g. press re- lease $10 \mathrm{yr}, 20 \mathrm{yr}$ after the last disaster). Pictures of local historic flooding events can be used to establish a real reference and promote the risk awareness, because pictures are able to touch the viewers' emotional spots (Lopes, 1992 in Hagemeier-Klose and Wagner, 2009). Thus, it is important to involve people emotionally (positively!), e.g. by involving flood witnesses - but people should not be made afraid, but rather their awareness should be raised. This may result in an enhancement of the people's willingness to pay attention to or rethink self-protection measures. Events like river festivals, connected with training shows of civil protection units or flood marks and other symbols that illustrate the water level of past floods, contribute to long-lasting risk awareness. Another starting point is the distribution of "welcome packages on flood risk management": such information, provided for new residents, can also be an important tool. New citizens are unaware of flood risks (especially when events appeared a long time ago) and are therefore insensible for this matter. Again, it must be pointed out that you have to raise the sensitivity of new citizens to the topic, without stirring up hysteria. The info material should firstly provide general information and refer to more detailed information sources. This can be an own category of flood risk management on the community's website (parallel to other local issues), which shall be installed. Also the co-ordination of the information and communication process could - if possible and if it makes sense - be allocated to an established and commonly accepted local group or actor (Local Agenda 21 group, environmental group, citizens' initiative) or already existing civil protection initiatives (e.g. avalanche commission). Emergency training and education for emergency managers is also a promising activity. For example, in the Italian region of Lombardy, a standard for emergency preparedness trainings is established. 
Particularly interesting is the fact that special courses for municipal mayors are offered with instructions about their responsibilities and duties (Alexander et al., 2009). Communication material and public participation tolls shall be regularly evaluated, and it shall be tested what material really improves risk perception. By using such an on-going evaluation concept, authorities in charge of the flood risk management process are able to take corrective action when regarding weakening performance.

\section{Conclusions}

The aim of the ERA-Net CRUE-funded project IMRA was an optimisation of the flood risk management process by increasing procedural efficiency with an explicit involvement strategy. To reach this goal, two new approaches for dealing with risk perception and risk communication (social milieu approach and risk governance assessment tool) were tested in a strategic framework with common methods (e.g. stakeholder analysis tool) in order to improve the active involvement of interested parties in flood risk management (stakeholders). These approaches are in the focus of this article, where two main questions were asked that relate directly to the requirements of the EU Flood Risk Management Directive:

- How can stakeholder and public involvement be improved in risk communication?

- How can the quality and fairness of the flood risk management processes be guaranteed?

In the case studies that were carried out, stakeholder workshops have shown that the implementation of the EU Flood Risk Management Directive in the member states needs communication about and definition of responsibilities of the stakeholders in order to avoid inefficiency or vacuum of responsibilities. This is due to the fact that the implementation of the directive requires new ways of involving stakeholders and the public. The analysis of stakeholders, their roles and responsibilities and also their demands is an important basis for anchoring the flood risk management process in the political and administrative network. In this respect, the risk governance assessment tool mainly helps to improve the involvement of the relevant stakeholders. For the authority in charge of the governance process, it helps to identify the relevant stakeholders and to assess the performance of the process according to risk governance principles. This also includes taking care of the interests of other stakeholders. Further, by opening the assessment to external views of the stakeholders, it helps the authority in charge to prioritise and optimise its actions and on the other hand to involve them directly. As the common risk governance principles also touch aspects related to the public (such as trust or accountability), also public involvement is indirectly increased. At the same time, this also increases the fairness of the risk management process.
In contrast, the social milieu approach mainly helps to improve the quality of the flood risk management process as the public that shall be addressed is informed and involved in a custom-made way. This increases the efficiency of the communication process and at the same time the acceptance, as addressees do not feel over- or underchallenged. As it focuses explicitly on the public, it also helps to improve the involvement of the public in the risk communication process.

Nevertheless, both approaches have still potential for improvement and further development. For the risk governance assessment tool, the indicators could be even more customised to the specific regional or local situation. Some effort should be dedicated to a common development of indicators with the relevant stakeholders. This can be the starting point for any governance process. Further, it would be helpful to translate the language used for the description of principles and indicators to a less scientific and more practical form.

The social milieu approach was applied on a rather general level. However, authorities at the regional or local level could dedicate some effort in collecting more specific information about social milieus for the village or quarter level as this information helps to improve any kind of information policy at the regional or local level.

As both approaches involve stakeholders and the public, they help to set flood-risk management decisions on a broader basis: not only scientific knowledge is the basis for decisions but also local knowledge as well as stakeholder and public risk perceptions. This helps to increase the acceptance of such processes that often tend to step back against other priorities at the local or regional level - especially when the scientific basis is inconclusive due to uncertain future developments such as climate change or other socio-economic overthrows.

Acknowledgements. The project IMRA (Integrative flood risk governance approach for improvement of risk awareness and increased public participation) was funded in the framework of the 2nd ERANet CRUE Research Funding Initiative by the Federal Ministry of Agriculture, Forestry, Environment and Water management (BMLFUW, Austria), the Federal Ministry for Education and Research (BMBF, Germany) and the Institute for Environmental Protection and Research (ISPRA, Italy).

The figure presenting the Sinus Milieus ${ }^{\circledR}$ for Germany is used with kind permission of the SINUS-Institut, Heidelberg, Germany.

The authors would like to thank Aline Te Linde (Deltares, The Netherlands), Philipp Schmidt-Thomé (Geological Survey of Finland) and an anonymous reviewer for their critical remarks and the time they dedicated for reviewing the manuscript. Finally, the authors would like to thank the members of the ERA-Net CRUE Scientific Co-ordination Project for taking care of the publication process of this NHESS Special Issue.

Edited by: S. Mariani

Reviewed by: P. Schmidt-Thomé, A. Te Linde, and one anonymous referee 


\section{References}

Alexander, D., Bramati, L., and Simonetta, M.: Emergency Preparedness Training and Education in Lombardy Region, Italy: Survey of Supply and Demand, Natural Hazards Review, 10, 7783, 2009.

Arbter, K., Handler, M., Purker, L., Tappeiner, G., and Trattnigg, R.: Das Handbuch Öffentlichkeitsbeteiligung, Österreichische Gesellschaft für Umwelt und Technik (ÖGUT) und Bundesministerium für Land-, Forstwirtschaft, Umwelt und Wasserwirtschaft, Wien, 2005.

Bader, S. and Kunz, P. (Eds.): Klimarisiken - Herausforderung für die Schweiz“. Wissenschaftlicher Schlussbericht im Rahmen des nationalen Forschungsprogramms "Klimaänderungen und Naturkatastrophen”, NFP 31, Zürich, 1998.

Bundeskanzleramt and BLFUW - Bundesministerium für Landund Forstwirtschaft, Umwelt und Wasserwirtschaft (Lebensministerium), Standards der Öffentlichkeitsbeteiligung Empfehlungen für die gute Praxis, available at: http://www. partizipation.at/fileadmin/media_data/Downloads/Standards_ OeB/standards_der_oeffentlichkeitsbeteiligung_2008_druck.pdf (last access: June 2012), Vienna, 2009.

Burton, I., Kates, R., and White, G.: The environment as hazard, Oxford, NY, Oxford University Press, 1978.

Carina, E. and Keskitalo, H.: A framework for multi-level stakeholder studies in response to global change, Local Environment, 9, 425-435, 2004.

CARPE DIEM project: Critical Assessment of available Radar Precipitation Estimation techniques and Development of Innovative approaches for Environmental Management, available at: http://carpediem.ub.es/results/status/Final_Report_Executive_ summary.pdf (last access: August 2012), Final Report, Executive Summary, 2004.

Evers, M., Maksimovič, Č., Jonoski, A., Lange, L., Ochoa Rodriguez, S., Dinkneh Teklesadik, A., and Makropoulos, C.: Decentralised Integrated Analysis and Enhancement of Awareness through Collaborative Modelling and Management of Flood Risk (DIANE-CM), 2nd ERA-NET CRUE Research Funding Initiative - Final Report, 2011.

Festinger, L.: A theory of cognitive dissonance, Evanston, Il, 1957.

Festinger, L. and Carlsmith, J. M.: Cognitive consequences of forced compliance, J. Abnorm. Soc. Psych., 58, 203-210, 1959.

Figueiredo, E., Valente, S., Coelho, C., and Pinho, L.: Coping with risk: analysis on the importance of integrating social perceptions on flood risk into management mechanisms - the case of the municipality of Áqueda, Portugal, J. Risk Res., 12, 581-602, 2009.

Firus, K., Fleischhauer, M., Greiving, S., Stickler, T., D’Andrea, A., Ferranti, C., Flex, F., Kobotschnig, G., Fangucci, G., Scheibel, M., Ebers, M., Sereinig, N., Malvati, P., Grifoni, P., Bagnini, S., Guzzo, T., Vitale, V., and Wanczura, S.: IMRA - Integrative flood risk governance approach for improvement of risk awareness and increased public participation, 2nd ERA-NET CRUE Research Funding Initiative - Final Report, 2011.

Geipel, R., Härta, R., and Pohl, J.: Risiken im Mittelrheinischen Becken, in: Deutsche IDNDR-Reihe no. 4, Bonn, 1-42, 1997.

Hagemeier-Klose, M. and Wagner, K.: Risikokommunikation in der EU-Hochwasserrisikomanagementrichtlinie - Eine Evaluation von Maßnahmen der Öffentlichkeitsarbeit, in: Tagungsband zur 1. Veranstaltung des Forums der EU-HWRM-RL am 26. Juni 2009 in Dresden, 41-56, 2009.
INTEGRAL: Die Sinus Milieus ${ }^{\circledR}$ in Österreich, available at: http: //www.integral.co.at/de/sinus/milieus_at.php (last access: June 2012), 2011.

IRGC - International Risk Governance Council: White paper on risk governance: Towards an integrative approach, Geneva, IRGC, 2005.

IRGC - International Risk Governance Council:Risk Governance Deficits - An analysis and illustration of the most common deficits in risk governance, Geneva, IRGC, 2009.

ISTAT: Annuario statistico italiano 2008, available at: http://www3. istat.it/dati/catalogo/20081112_00/ (last access: June 2012), 2008.

ISTAT: Annuario statistico italiano 2009, available at: http://www3. istat.it/dati/catalogo/20091120_00/ (last access: June 2012), 2009.

IT.NRW: Statistik, available at: http://www.it.nrw.de/statistik/index. html (last access: June 2012), 2011.

Kahnemann, D., Slovic, P., and Tversky, A.: Judgment under uncertainty: heuristics and biases, Cambridge, Cambridge University Press, 1982.

Kingdon, J. W.: Agendas, Alternatives, and Public Policies (2nd edition), Harper, 1995.

Kleinhückelkotten, S.: Soziale Milieus als Zielgruppen in der Bürgerbeteiligung und Engagementförderung, available at: http://www.21-kom.de/fileadmin/user_upload/PDFs/ 02_Sinus_Milieus/Soziale_Milieus_und_Engagement.pdf (last access: June 2012), Freiburg, 2007.

Larsson, G.: Spatial Planning Systems in Western Europe, an overview, IOS Press - Delft 2006, 2006.

Löfstedt, R.: Risk management in post-trust societies, Houndmills, Basingstoke, Hampshire, New York, 2005.

MIDIR project: Multidimensional Integrated Risk Governance - A comprehensive and scalable approach to governance for resilience, sustainability and performance monitoring of organizations and networks - Introduction to methodology, avalable at: http://www.raumplanung.tu-dortmund.de/irpud/fileadmin/ irpud/content/documents/projects/MIDIR_Final_brochure.pdf (last access: June 2012), 2008.

Milly, P. C. D., Betancourt, J., Falkenmark, M., Hirsch, R. M., Kundzewicz, Z. W., Lettenmaier, D. P., and Stouffer, R. J.: Stationarity Is Dead: Whither Water Management?, Science, 319, 573-574, 2008.

Newman, P. and Thornley, A.: Urban Planning in Europe; International competition, national systems and planning projects, Routledge, London, 1996.

Regione Umbria: Statistica, avaiable at: http://www.statistica. regione.umbria.it/mediacenter/FE/home.aspx (last access: June 2012), 2011.

Rivolin, U. J.: Conforming and Performing Planning Systems in Europe: An Unbearable Cohabitation, Planning, Practice and Research, 23, 167-186, 2008.

Roser-Renouf, C. and Nisbet, M. C.: The measurement of key behavioral science constructs in climate change research, available at: http://195.37.26.249/ijsc/docs/artikel/03/3 05_IJSC_Research_Roser-Renouf.pdf (last access: June 2012), International Journal of Sustainability Communication, 3, 37-95, 2008.

SINUS-Institut: Sinus-Milieus, available at: http://www. sinus-institut.de/loesungen/sinus-milieus.html (last access: 
June 2012), 2011.

Sjöberg, L.: Factors in Risk Perception, Risk Analysis, Society for Risk Analysis, 20, p. 9, 2000.

Slovic, P.: Perception of risk, Science, 236, 280-285, 1987.

Slovic, P., Fischhoff, B., and Lichtenstein, S.: Rating the risks: the structure of expert and lay perceptions, in: Environmental impact assessment, technology assessment, and risk analysis, edited by: Covello, V. T., Mumpower, J. L., Stallen, P. J. M., and Uppuluri, V. R. R., Berlin, Heidelberg, New York, Springer, 4, 131-156, 1985.

Stadt Leichlingen: Bevölkerungsstatistik Leichlingen, available at: http://www.leichlingen.de/Bevoelkerungsstatistik.332.0.html (last access: June 2012), 2011.

Statistik Austria: Statistiken, available at: http://www.statistik.at/ web_de/statistiken/index.html (last access: June 2012), 2011.

Stickler, T., Fleischhauer, M., Greiving, S., Sereinig, N., Koboltschnig, G., Malvati, P., Grifoni, P., and Firus, K.: Planning and Evaluating with New Participatory Flood Risk Management Tools, Findings From Case Studies in Austria, Germany and Italy, in: UFRIM - Urban Flood Risk Management, Approaches to enhance resilience of communities, Proceedings from the International Symposium, edited by: Zenz, G. and Hornich, R., 21-23 September 2011, Graz, Austria, 35-40, 2011.

UNISDR - United Nations International Strategy for Disaster Reduction Secretariat: Living with risk: a global review of disaster reduction initiatives, New York and Geneva, UN, 2004.
UNISDR - United Nations International Strategy for Disaster Reduction: Hyogo Framework for Action 2005-2015: Building the Resilience of Nations and Communities to Disasters, Geneva, UN, 2005.

van Asselt, M.: The complex significance of uncertainty in a risk era: logics, manners and strategies in use, in: Risk Assessment and Management, No. 2/3/4, 1250-158, 2005.

Wagner, K.: Wie sag ich's der Bevölkerung? Evaluation einer Ausstellung und eines Lehrpfads zum Thema "Alpine Naturgefahren”, Geographica Helvetica, 60, 54-61, 2005.

Wagner, K. and Suda, M.: Natural hazards in the perspective of the public - a big black box, Internationales Symposion Intraprevent, 2004-RIVA/Trient, IX, 285-296, 2004.

WBGU - German Advisory Council on Global Change: World in Transition: Strategies for Managing Global Environmental Risks, Annual Report 1998, Berlin, Springer, 2000.

Website Balanced Scorecard: Was ist eine Balanced Scorecard?, available at: http://www.balanced-scorecard.de/konzept. htm (last access: June 2012), 2011.

Weichselgartner, J.: Naturgefahren als soziale Konstruktion: Eine geographische Beobachtung der gesellschaftlichen Auseinandersetzung mit Naturrisiken, Shaker Verlag, Aachen, 2001.

Young, O. R.: The Institutional Dimensions of Environmental Change, Fit, Interplay, and Scale, Cambridge, Mass., London, MIT Press, 2002. 